\title{
IMPACTS OF US RESIDENTIAL TOURISM IN THREE NORTHWEST MEXICAN COASTAL DESTINATIONS: MAZATLÁN, SINALOA; CABO SAN LUCAS, BAJA CALIFORNIA SUR AND PUERTO PEÑASCO, SONORA
}

\author{
Omar LIZARRAGA*
}

\begin{abstract}
The objective of this paper is to present an analysis of the social and environmental impacts generated by residential tourism in three destinations in northwestern Mexico. In the theoretical framework a critical review of this tourism modality is presented, as well as its main statements. To achieve the objective, non-participant observation was made, and official sources of the federal government were consulted. The results show that residential tourism in this region generates important negative social, cultural, political and environmental effects, such as social polarization, hoarding of natural resources, privatization of public spaces and degradation of the ecosystem. The study allowed to identify these effects and compare them between the three destinations.
\end{abstract}

Keywords: Residential Tourism. Social and Cultural Impacts. Political Impacts. Environmental Impacts. Mexico.

\section{IMPACTOS DO TURISMO RESIDENCIAL ESTADOUNIDENSE EM TRÊS DESTINOS COSTEIROS DO NOROESTE DO MÉXICO: MAZATLÁN, SINALOA; CABO SAN LUCAS, BAJA CALIFORNIA SUR E PUERTO PEÑASCO, SONORA}

Resumo: O objetivo deste trabalho é apresentar uma análise dos impactos gerados pelo turismo residencial em três destinos no noroeste mexicano. No referencial teórico do artigo, existem visões críticas dessa modalidade turística e de suas principais características. Para atingir o objetivo, foi feita uma observação não participante e consultadas fontes oficiais do governo federal. Os resultados mostram que o turismo residencial nessa região gera significativos impactos sociais, culturais, políticos e ambientais negativos, como polarização social, captação de recursos naturais, privatização de espaços públicos e degradação de ecossistemas. O estudo permitiu identificar esses efeitos e compará-los entre os três destinos.

Palavras chave: Turismo Residencial. Impactos Sociais e Culturais. Impatcos Políticos. Impactos Ambientais. México.

\section{IMPACTOS DEL TURISMO RESIDENCIAL ESTADOUNIDENSE EN TRES DESTINOS DE LA COSTA NOROESTE DE MÉXICO: MAZATLÁN, SINALOA; CABO SAN LUCAS, BAJA CALIFORNIA SUR Y PUERTO PEÑASCO, SONORA}

Resumen: El objetivo de este trabajo es presentar un análisis de los impactos que genera el turismo residencial en tres destinos del noroeste mexicano. En el marco teórico del escrito se encuentran visiones críticas de esta modalidad turística y sus principales argumentos. Para lograr el objetivo se hizo observación no-participante y se consultaron fuentes oficiales del gobierno federal. Los resultados muestran que el turismo residencial en esta región genera importantes impactos sociales, culturales, políticos y ambientales negativos, como polarización social, acaparamiento de recursos naturales, privatización de espacios públicos y degradación del ecosistema. El estudio permitió identificar estos efectos y compararlos entre los tres destinos.

Palabras clave: Turismo Residencial. Impactos Sociales y Culturales. Impatcos Políticos. Impactos Ambientales. México.

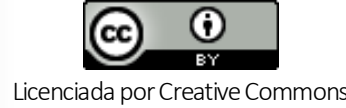

4.0 / Internacional CCBY 4.0
* PhD of Social Sciences / University Autonomous of Sinaloa (UAS) (2011). Master in Studies of United States and Canada / UAS (2006), Degree in Tourism / UAS (2004). Professor and researcher of full time at Faculty of Social Sciences UAS, postgraduate in Social Sciences. Member of the National Academy of Sciences in Mexico, and member of National System of Researchers (SNI, Mexico, level 1). https://orcid.org/0000-0001-9774-4660 [omar lizarraga@uas.edu.mx] 


\section{INTRODUCTION}

For Huete (2008) the term "Residential Tourism" was incorporated into the academic debate by Francisco Jurdao in his 1979 book "España en venta: compra de suelo por extranjeros y colonización de campesinos en la Costa del Sol". In the following years the term residential tourism has been used by different researchers to refer to a diverse set of processes difficult to delimit, in which the intense economic activity around the real estate business with specific aspects of tourism, and these, with some forms of the new immigration forms and residential nature.

This type of mobility in search of amenity spaces for longer seasons than traditional tourists in european and american literature has been called: Lifestyle Migration (Benson and O'Reilly, 2009; Muller, 2019), Amenity Migration (Janoschka, 2008), Priviledged Migration (Croucher, 2009) North-South Migration (Balslev, 2008; Bozic, 2006), Retirement Migration (Gustafson, 2008; Rodriguez, 2005), Consumption-Led Movility (Huber, 2005) and the most common: Residential Tourism (Bielza and Bohl 2009; Huete, 2008; Cañada, 2013).

This mobility known since the fifties and sixties, on the early twenty-first century has been increasing rapidly to various Latin American countries such as Costa Rica, Panama, Venezuela, Argentina, but especially to Mexico. Population from United States in this country living permanently or temporarily represents the most significant residential tourist and migratory flow with 56,906 US citizens officially registered as permanent residents at the National Migration Institute (2016).

In the citizenry of the most economically advanced societies has emerged nostalgia for landscapes and lifestyles difficult to find in their usual environment, which has contributed to the emergence of these new forms of residential mobility (Mazon et al, 2009). This permanent and semipermanent mobility has become one of the most important characteristics of demographic and social change in developed countries. It is a clear indication of the new types of human mobility, which experience a major intensification since the last decades of the twentieth century and early twentyfirst century.

The main question that guided this research was ¿What are the social, cultural, political and environmental impacts of residential tourism in host communities? In this paper we proposed to answer this question.

\section{RESIDENTIAL TOURISM: A CRITICAL REVIEW}

Tomás Mazón and Antonio Aledo (2005) after carrying out a review of the literature, since the perspective of the economic production, they define Residential Tourism as: "The economic activity that is dedicated to the urbanization, construction and sale of houses that makeup the extra-hotel sector, whose users use them as accommodation for long periods or to reside, permanently or semi-permanently, outside their places of habitual residence, and which respond to new forms of mobility of advanced societies" (p.18-19).

Cañada (2013:71) defines it as

"the phenomenon in which people settles temporarily or permanently in a tourist destination and buys a house, apartment or land. These are often people of European or American origin who move to the south in search of a more relaxed lifestyle, lower cost of living or better weather".

Two pioneer studies of residential tourism were made in Spain in the seventies. They were made by the teachers of the University of Alicante, Mario Gaviria (1974 and 1976) and Francisco Jurdao (1979 and 1990). Since those years these researchers had a critical approach to this social phenomenon. According to Mario Gaviria (1974), cheap and exploited immigration is the result of residential tourism. "Tourism Braceros", he called them; given the temporary nature of the jobs offered by this industry.

During the sixties, the hotels and tour operators, but also the villas and apartments were driven by Spanish entrepreneurs, but in the early seventies foreign capital was quickly replacing the Spanish capital, taking control of the hospitality industry, performing a figure that Gaviria defined as a neocolonialism of quality space (Gaviria et al 1974). "The natural spaces within Europe, are increasingly scarce, and in a first stage were used as an invasion by the inhabitants from European advanced industrial societies such as the Netherlands, England or Germany" (p.89).

For the first time, Gaviria made a critical study of the real estate business in the residential tourism sector. He addressed social, economic and environmental impacts in this work: economic and 
social polarization, land speculation, exploitation of labor, etc. What was considered an income from tourism; it was actually income for selling territory, Gaviria argued (Gaviria, 1974).

Two years later (Gaviria, 1976), wrote another sociological reflection of the phenomenon, he coordinated the work entitled "El Turismo de invierno y el asentamiento de extranjeros en la provincia de Alicante" (The winter tourism and the settlement of foreigners in the province of Alicante), in which he used for the first time the term residential tourist.

That paper highlights that the province of Alicante was the second most visited for foreign residents in Spain, surpassing in cosmopolitalism to Madrid or Barcelona. Gaviria, also highlighted in this study the social and economic inequality of domestic immigrants and residential tourists from United Kingdom. At first, they migrated to work in hospitals, cementeries, restaurants, while the latter were coming in search of leisure spaces.

On the other hand, Francisco Jurdao (1979 and 1990), another pioneer in the study of Residential Tourism in Spain, in his work, he focuses on analyzing the phenomenon particularly in the town of Mijas, and it distinguishes the phenomenon to traditional or itinerant tourism. He speaks of an "Alternate Migration" (Jurdao, 1979, p.14). In this paper the author analyzed the negative impacts that caused the arrival of foreigners to the Spanish coast. He deeped into the problem of urban corruption manifested in property speculation.

This tangible problem adds to the difficulty of communication that complicates the social relationship with the local population. The author concludes that "economic miracle that accompanied the Spanish hotel tourism, has been replaced by the apocalyptic vision of a residential tourism: foreign retirees who have a political priority over the local people locked in their reserves on Mediterranean coast of Spain" (p.27).

In the case of the Spanish coasts, where the associated changes have been shown with greater intensity, residential tourism activity has been an important accelerator in the process of social change in the country. This phenomenon, due to its characteristic of migratory processes, has caused important changes in the demographic composition of the localities and a very important transformation in the landscape. It has also led to the disappearance of traditional activities, and local culture has been replaced by a new cosmopolitan and global culture, leading also to fragmented communities and new forms of social interaction (Aledo, 2008; Aledo, García, and Ortiz, 2010).

The real estate construction has been benefited more widely, however, soil consumption creates problems due to collision with other productive uses of the land (Serrano, 2003). It has boosted economic growth in some communities; it has even been a major agent of social and cultural change in these regions, but this model of tourism development is not exempt of problems and limitations (Aledo and Mazón, 2004).

Recently the residential tourism is still seen from a critical perspective by sociologists such as Ernest Cañada (2007 and 2013), who includes the main impacts of residential tourism in three blocks: environmental, economic and social. The first, derived from the substantial increase in energy needs, overexploitation, the change in use of land, and the destruction of resources and ecosystems, as well as waste generation. Economically, creating precarious jobs and destroying traditional economic activities, causing an increase in prices of essential goods and repatriating the capital towards the global center. Social impacts arise from asymmetric relations between the tourism and local population, the erosion of human and intangible values, and the alteration of social structures in the destinations.

Since the 1950s, and at the same time as tourism was developing, a powerful artisanal fishing based economy that generated employment for thousands of workers was gradually disappearing in Spain. Tourism also triggered prices for land and housing, especially those closer to the sea, which are now destined for tourism infrastructures and second residences (Gascon and Cañada, 2016).

Several scholars from latin america have documented Residential Tourism and its impacts in Brazil (Demajorovic, et al., 2011; Aledo, et al, 2013); Chile (Hidalgo and Zunino, 2011); Costa Rica (Barboza, 2016) and Mexico (Lizárraga, 2012; Hiernaux, 2005; Peraza and Santamaría, 2017). 
Table 1. Authors and main contributions.

\begin{tabular}{|l|l|l|l|}
\hline Author & Period & Country & Critic of the author to residential tourism \\
\hline Mario Gaviria, Francosco Jurdao & 1970 's & Spain & $\begin{array}{l}\text { Social polarization, speculation of land, } \\
\text { environmental damage }\end{array}$ \\
\hline $\begin{array}{l}\text { Antonio Aledo, Tomás Mazón, Raquel Huete, } \\
\text { Alejandro Mantecón }\end{array}$ & $2000-2010$ & Spain & $\begin{array}{l}\text { Migratory focus, transformation of the landscape } \\
\text { and economic activities. }\end{array}$ \\
\hline Jacques Demajorovic & 2010 & Brazil & $\begin{array}{l}\text { Growth of residential complexes and socio- } \\
\text { environmental damages }\end{array}$ \\
\hline Rodrigo Hidalgo, Hugo Zunino & 2011 & Chile & Power relations and urbanization \\
\hline $\begin{array}{l}\text { Esteban Barboza } \\
\text { Omar Lizárraga, Daniel Hiernaux, Brianda } \\
\text { Peraza and Arturo Santamaría }\end{array}$ & 2016 & $\begin{array}{l}\text { Costa } \\
\text { Rica }\end{array}$ & Colonialismand gated communities \\
\hline
\end{tabular}

Source: author's elaboration.

\section{DATA AND METHOD}

To know the social and environmental impacts, a nonparticipating observation was conducted in the three destinations during the period between 2012 and 2016. The official data of the Environment and Natural Resources Ministry (Semarnat, for the initials in Spanish) was also consulted; particularly we analyzed the Environmental Impact Manifestations of real estate developments in the areas in question, since these real estate developments are mostly owned by foreigners in the three destinations analyzed. The literature on the impacts of residential tourism was also consulted.

First, we made a review of the main theoretical approaches outlined by the Social Sciences to explain the tourist and residential mobility. Subsequently we conducted a review and analysis of bibliographical, documentary and hemerographic material in the three locations studied.

This study was geographically delimited to these three mexican locations because they are the most important tourist destinations of three states that according to the National Migration Institute are among the most populated by US citizens in the northwestern region of Mexico.

\section{IMPACTS OF RESIDENTIAL TOURISM IN NORTHWEST MEXICO}

\subsection{Mazatlán, Los Cabos and Puerto Peñasco, México}

These are three coastal tourist destinations which have their peculiar characteristics. Mazatlan is a traditional destination that boomed in the seventies and, currently in a phase of slow growth compared with other tourist destinations, however, it has gained the preference of the US citizens, especially retirees, as a permanent and semi-permanent residence. Los Cabos is a strategically planned tourist destination, relatively new, which for its urban planning, geographic characteristics and promotion, is the most visited by US tourists in Mexico. Puerto Penasco is a tourist destination close to the US border (100 kms.), which geographical location has attracted Americans seeking a second home in Mexico. Social and environmental impacts generated by these touristmigration flows vary in the three places, because the dynamics with the local community and the environment is different.

The city of Mazatlan is the second largest in the state of Sinaloa. Tourism and fishing are the main economic activities. It is one of the main tourist coastal destinations in the country and has the second largest fishing fleet in Mexico. 30\% of municipal Gross Domestic Product (GDP) is generated by the tourism industry, and Mazatlan represents the $72 \%$ average of state tourism. The INM recorded until the end of 2015 to 1.931 US citizens who lived in the state of Sinaloa, of which, $90 \%$ of them lived in Mazatlan (INM, 2016).

On the other hand, Los Cabos is a touristic corridor, whose length is 33 kilometers and is located at the southern of Baja California Sur. 90\% of municipal GDP is generated by the tourism. In this state, the National Migration Institute, recorded in the same period of 2015, to 6.270 US citizens who lived in the state of Baja California Sur (INM, 2016). According to this institute, in Los Cabos is concentrated the $88 \%$ of the American population of the state. Baja California Sur is the third Mexican state with the largest population from the United States, only after Jalisco and Baja California. 
The city of Puerto Penasco in Sonora is another destination in which the most important economic sector is related to real estate and services. In recent years tourism was developed as an important activity that affected the community and the economy devoted to fishing, to become one of the fastest growing cities in northwest Mexico. Puerto Peñasco produces $33 \%$ of income from tourism in the state of Sonora. National and state public policy and private investment focused on making Puerto Penasco in a residential destination aimed to the population from the US southwest (Enriquez, 2008). The state of Sonora has the record of 3,670 US citizens, of which $32 \%$ of them lies in the municipality of Puerto Penasco (INM, 2016).

\subsection{The Main Impacts of Residential Tourism}

The mass media highlights the economic benefits that represent the arrival of this type of tourism, which is true, but little is said about the negative impacts it has on the regions of destination. This section will discuss the impacts generated in the region of northwest Mexico.

Tourism is an economic activity that has experienced strong global growth, contributing to development of many regions and countries. But usually in developing countries, this activity provides an overview of irreconcilable extremes; it combines two polarized social spheres and interdependent physical spaces. It also support practices that undermine natural resources, dissolves cohesion of ties in local societies, and distribute wealth based on a pattern that deepens social inequalities (Méndez, 2008).

In this case, we detect some important effects of the development of second homes of foreigners: Social polarization and hoarding of resources. Environmentally it represents erosion and pollution of beaches.

\subsubsection{Social polarization}

The residential-tourism destinations today show a marked process of physical transformation of the territory and landscape, establishing a clear case of spatial duality between sectors of "winners" and "losers" (Enriquez, 2008). In Puerto Peñasco, Sonora, the coastal zone established a curtain of hotels and condominiums in front to the beach with superior urban services and facilities, infrastructure for entertainment, golf and spas. It is a tourist activity directed essentially to the North American public.

Second, Puerto Penasco is actually in a process of rapid transformation. As we observed during the field work, the differences are prominent in terms of the provision of clearly inferior services and urban infrastructure with respect to the hotels zone. The old town center where fishers live is being displaced by the business and tourism-related services. Spaces used for selling crafts, food and nightlife predominate. The adjacent area to the city center, north and east, is the residence of employees in commerce and urban services, with a low level of urbanization, these are the new sections of the town recently created by the flow of immigrants employed in the construction and tourism services, is contrasting with respect to coastal area.

Precariousness and social exclusion are common as well as the lack of potable water, electricity and drainage. Poor neighborhoods form a habitat defined by the material and social hardship, people has to endure the extreme weather of summer and winter in the Sonora Desert. Cardboard materials and galvanized steel used in the construction of housing complicate the situation (Enriquez, 2008).

Martinez (2008), mentions that the original urban core reports worrying indicators such as: segregation, mass migration, explosive growth, lack of basic services, demand for land, water and energy, depletion of local ecosystems, social vulnerability, and predominance of vertical forms of urban management that limit social participation. Puerto Penasco as a touristic destination is divided into two, on one side the beach strip with hotels and residential condominiums, high level of equipment and urban infrastructure and social exclusiveness; on the other hand, the rapidly growing city, sandy streets, poor drainage and high social polarization.

The new development of houses along the coast of Puerto Penasco, constitute a separate urban city, and foreigners unwilling to integrate to its local residents. Predominates US citizens, who only required local people for domestic work and occasional supplies. The sectors in Puerto Penasco where the residential tourists live, are poorly connected with the city, both, socially and urban. They represent a model that tends to dispersion and 
fragmentation of the territory as in the case of La Choya and Las Conchas, these are small isolated towns and not very linked to the city (Enriquez, 2009).

In Puerto Peñasco there are developments and condominium towers on the coast, which prevent entry of people to the beach, even when under the national law, the free entry is a right of all citizens. The closure to the exterior is an important element for the sale of tourist residences, since the marketing on safety is based on the exclusive privacy with respect to the city as a whole and social differentiation. But despite the advantages that the model represents for homeowners, it imposes new forms of peaceful coexistence; on the one hand in the urban context it is difficult the free movement around the city. The privatized neighborhoods are inserted into the landscape, breaking the urban continuity and forcing people to surround these small fortresses, marking differences between those inside and those outside (Carrasco, 2008).

The strip of hotels and condominium complexes are carefully kept separated from the city, the distance is not only physical but also social. Territorially, construction activity has formed a prohibitory space for locals. Houses and condominiums and upscale hotels are protected by security systems that insulate and protect the comfort and pleasure of the foreigner's social imaginaries (Enriquez, 2009).

The displacement and segregation that is manifested in the fishing community of Puerto Peñasco has occurred largely because real estate development of the town has displaced fishermen from areas that had been traditionally held for their activity, to now be filled by new residents in spaces for recreation and relaxation.

Another study of two touristic destinations in Sonora (Enriquez and León, 2015) points out the same problems than Puerto Peñasco: 1. the rapid transformation of the natural environment and its replacement by hotel buildings and second homes, and 2. the social and functional segregation of the territory, dividing the tourist development zones of the rest of the village.

In the case of Mazatlan, a similar situation occurs with jobs, a large volume of temporary employment is generated during the time of construction and consolidation of the architectural projects, it encourages important migrations, once completed real estate developments, they become a conglomerate of population demanding services and employment in the tourist destination (González and Santana, 2009).

Bringas (1997) notes that in tourist destinations, the consumer expectations generated from the most economically advanced societies, imitation processes are emphasized especially in young people; in fashion, in music, values, among others; subjecting the local people by visitors. Similarly, many of the goods and services consumed by local residents increases because of tourists high demand, this arises an inequality of domestic economy. In the eyes of the host society, the tourism brings wealth, and tourists receive the best food, services, spaces, best beaches; processes that can generate antipathy or rejection of the visitor by the poorer population.

The transformations of tourism also produce spatial segregation in places where it occurs, that is, exclusiveness to the tourist areas is created. Often this organization of space has its origin from the expropriation of agricultural land, which has led to the expulsion of the original inhabitants. The expropriation of these lands in Mexico, usually justified on the argument that the native population will be participant in the economic benefits that tourism generates, in most cases they do not.

In Mazatlan, it is also occurring this duality or social polarization. On one side, there are the enclaves where the exaltation of consumption and expensive lifestyle for residential tourists. In contrast, exclusion and segmentation of the territory among the local population that shows the hardness of inequality, social segregation and marginalization. Urbanism expressed by resort cities for residential tourism results from the spatial reorganization of the exclusion. In defense of security and the desire of tranquility, barriers are erected to physically separate the other disadvantaged groups.

In the case of Los Cabos, Cabral (2007) argues that the growing tourist development has brought serious social problems due to the economic polarization. Many of the indicators of marginalization that occur among the rural population in agricultural fields, are also present in the peripheral neighborhoods of Cabo San Lucas, including problems such as child prostitution. The local authority speaks of more than 100,000 people in vulnerable conditions in the state, especially in rural areas, but also notes that this 
condition of vulnerability increases in the municipality of Los Cabos.

The growth of tourism developments in this region results in many social problems, domestic migration and settlement of immigrants in poor neighborhoods that appear rapidly without any services and immediately begin to demand water, electricity and schools (Cabral, 2007).

Until 2016, many of the jobs required by the municipality of Los Cabos are low-skilled, easily absorbing regional workers from traditional productive sectors, so that when it happens, the local social structure becomes more complex with the emergence of an immigrant population often marginalized that comes to a new one, but with less job security, longer working hours, labor flexibility and lower quality of life.

Usually, the way to solve the demand for skilled workers that the activity requires is by hiring immigrants from abroad, usually from United States, while the unskilled workers come from the south of Mexico. Unskilled labor in tourism is characterized by low wages, the abundance of temporary contracts, long working hours and poor safety conditions (Canada, 2007). These migrations from southern Mexico, in contrast to the north, are concentrated in Los Cabos, they highlight the social and economic polarization in the region.

In the case of Mazatlan, has been documented before (Lizarraga, 2014) that "most of the local inhabitants see the arrival of foreigners to their community positively, since they perceive benevolent qualities of the Anglo-Saxon culture, and in many cases, a source of employment. But there are also critical positions, particularly from the perspective of people of middle and high socioeconomic status. On the other hand, the US citizens describe Mexicans as kind, hard-working, friendly and helpful, but also unpunctual and noisy. These differences in lifestyle often lead to minor conflicts" (p.69).

\subsubsection{Grabbing resources}

Wastage and hoarding of resources such as water, is visible in residential developments in the northwestern region of Mexico, even though this is a public good, it has been privatized by the administration of desalination plants. These plants were financed with public capital, while its operation was concessioned to a Spanish company Inima, a subsidiary of $\mathrm{OHL}$ (the largest Spanish construction company), which has taken control of the operation of this public service. This has caused many conflicts of law and constitutional order. This has led to severe structural contradictions and policies that involve multiple instances of the federal government and public officials in service. A statistical projection states that in these resorts for every hotel room is attracted an average of more than 19 labor immigrants who require work and services (Salazar, 2009).

In Mazatlan providing basic resources such as water has become a serious problem. For Ramirez (2006), the water in our nation has become a topic of national security, due to its increasing scarcity, its availability has fallen alarmingly, thus the development of some regions is in risk, and even there are risks of international conflicts to the limited availability. For this author, in Mazatlan due to population growth, demand, climatic factors, overexploitation, pollution and its waste as common practices, the risk of scarcity is present.

Due to high economic resourses of US citizens in Mazatlán, they live in the best residential developments, and of course, they are the first to be provided of water. Is common to see in their houses pools and large gardens, while much of the local population is often limited to this vital resourse.

Tourism and real estate business in Mazatlan has reached a very rapid growth that covers large areas of coast strip. Such development causes the hotels, to compensate the water deficit, digging artisan's holes which chemical property is of a high salt content (Ramirez, 2006).

Ramirez (2006) displays a very critical future, if the constant increase in demand for water continues in the city, will cause drastically a reduction of water levels in the aquifers. This extraction encourages the overexploitation and intrusion of saline sea water that contaminates the aquifer, so the social, economic and environmental damage to the city will be incalculable.

Today, local authorities highlight the economic benefits the residential tourism brings to the region, however, they ignore the fact that the benefits are just for some investors, and the impacts are for the local population, and even they are threatening the development of the cities. 
In Puerto Penasco and Los Cabos, being desert areas, the water becomes an important value. Hotels and residential areas of highest value are the privileged, while the inhabitants of poor neighborhoods are often limited. As we noticed in multiple field visits, the local people is often forced to store water in containers for domestic use, while in the residential complexes residents have pools and large gardens making an excessive use of water.

\subsubsection{Cultural Impacts}

For Cañada (2007), international tourism has become, in recent decades, one of the main factors of cultural interrelation. Tourist and host have the opportunity to observe exotic uses and customs. They receive and thus process information that can lead to changing their norms, values, customs and material culture.

For Cristina Oehmichen (2013), tourism originates an inter-ethnic relationship, because the places of origin of tourists are physically and culturally different, and often distant from the places of destination. So we can say that tourism implies a social relationship between guests and hosts. That is, the meeting between the two constitutes the heart of the tourism system.

Although the types of cultural impact that residential tourism can cause can be very diverse, there are some that have provoked a special debate and interest. Among them, we can highlight their ability to consolidate or face stereotypes, to favor processes of change in social norms and values, or to revalue or damage heritage.

For example, the arrival of this kind of tourists to Mazatlan, Cabo San Lucas and Puerto Peñasco has influenced religious practices, as americans bring with them their protestant christian religion that has increasingly grown in these traditionally Catholic destinations. For example in Cabo San Lucas, we interview attendees of Cabo English Church, and according to their pastor Mike Gratzke, the number of attendees of mexican nationality has increased since their arrival in 2001 (Lizárraga, 2012: 154). The same happens in Mazatlan and Puerto Peñasco.

Food is also another cultural aspect that usually affects residential tourism. As a reflection of Western food trends, regional diversity tends to disappear in favor of these food models. The appearance of fast food chains is the most prominent example in the three destinations analyzed here. Today we can find successful establishments of the multinational McDonalds and Burguer King in the most central locations. In them a clientele, both local and foreign, enjoys a similar food supply in all parts of the world.

In terms of mutual perception, the power asymmetries determine how mexicans and americans perceive each other; differences in history, religion, ethnicity and language complicate the relationship between these two communities, however both social groups so far coexist in an environment of respect. According to a previous study (Lizarraga, 2014) in the case of Mazatlan, mexicans generally perceive americans as respectful, calm, calculating, punctual, clean, serious, orderly, reserved and collaborative.

On the other hand, americans describe mexicans as friendly, hardworking, family attached, friendly, helpful, cheerful, but also unpunctual and loud. These differences in lifestyle often cause minor conflicts. The majority of the local inhabitants in Mazatlan, see in a positive way the arrival of residential tourists to their community, because they see in them benevolent qualities of the Anglo-Saxon culture, and in many cases, a source of employment. It should be said that in that study we found critical positions regarding the social impacts generated by the massive arrival of Americans, particularly from the point of view of people of high socioeconomic status.

\subsubsection{Political Impacts}

For González (2012) in tourism, as in any social space, power relations and their conflict exist. In the attempt to model these relationships manifested in their representatives, four agents with particular interests involved in the tourist activity are presented: tourists, residents, the state manager and various categories of intermediaries.

The tourist from his place of origin is rational, independent and powerful actor in his travel initiatives; in the place of destination it is positioned against intermediaries, residents and even the State, depending on their travel routines of their information, management, mechanisms and fees. The residents, although the literature recognizes them as agents that exercise the least control over the tourist area that do not have an economic interest, 
behave as agents in power relations to react (in active or passive) resistance to tourists or approve the tourism projects.

The State is involved in the planning, production and execution of tourism to the extent that the remuneration obtained is distributed according to the power exercises of the agents involved. It includes city planners, urban heritage conservatives as well as politicians, those who work in tourist planning, execution, promotion and information centers operated by the government, public security personnel, site guards (González, 2012).

In residential tourism, the socio-political impact focuses mainly on the conflicts between urban planners of local governments, investors and local inhabitants, around the construction of real estate developments offered to tourists and foreign residents.

In the case of Mazatlan, protests against the construction of apartment towers are becoming more frequent as they claim to be affected by the increase in population density, to the extent that they have lost their peace in their neighborhood. Rodolfo Kelly, president of the Association of neighbors of the Gaviotas neighborhood, said that in the last two years they have built more than 20 buildings with apartments, with the aim of renting them to tourists through platforms such as Airbnb, which has increased the noise and traffic in this area.

"We are not against them doing their business, we know that developers seek to make money, but not at the expense of us and to affect our lives that we have had in this place for many years," he said (Cañedo, 2019).

The use of land is another political conflict in the three destinations. In Mazatlán has resulted in hoarding of historic buildings, a change of labor activities for certain segments of the population, land speculation, change in use of land, and economic inflation.

The Historic Center of this city is one of the most inhabited areas by US citizens. Even though the Federal Law on Monuments and Archaeological, Artistic and Historic Zones, points the obligations of owners of historic buildings, some Americans ignore the law. The director of the National Institute of Anthropology and History (INAH by the initials in spanish) said that "at least seven buildings in the
Historic Center have been, or are being changed without authorization of the institute".

In particular he points out the case of the US citizen Thomas who has made unauthorized changes to the building. The remodelling was suspended with labels, but the work continued. INAH has even called for the deportation of Thomas. He continues: "We struggled mainly with gringos who do changes and trample our national heritage, they do not listen, we have left notifications and they continue to work" (Contreras, 2009).

The use of space and particularly of the territory is of great importance in the assessment of the effects generated by the real estate development. Puerto Penasco with this urban and population growth, recreation of local residents has been modified for the enjoyment of new residents and tourists, generating a process of gradual displacement from the coast, which observation had always been one of the basic features of their lifestyle.

As a result, the coast is experiencing a drastic transformation of the landscape formed by sand dunes, desert flora, mangroves and wetlands, establishing in their place artificial and exotic landscapes. But also, the high density of hotel developments and condominium towers on the coast allowed the privatization, restricting access to the beach for the Mexican population.

Since the mid-1990s, the beach first line becomes land of consumption for leisure, transforming the local scenery with a curtain of buildings on the sea front, while the urban periphery expands occupied by a wide swath of poor neighborhoods (Méndez, 2008).

The central argument of many authorities that promote this kind of development is to generate taxes. This is partially true, but construction permissions are disbursed only once, and federal taxes are rarely returned in full to the host society; however, municipal spending on maintenance and provision of infrastructure and facilities are an ongoing expense for municipal governments, not to mention other processes such as cultural influence (Hiernaux, 2009).

In the municipality of Los Cabos it has radically transformed the social, cultural, economic and even political life of the community (Cabral, 2006). The residential flow from the United States has impact in 
the transformation of South Californian society. Many residents of the city have sold their land to US citizens for a few thousand dollars and they multiply these properties after their performance for the benefit of foreigners. There is an important activity of sale of land. Tulio Ortiz (in Cabral, 2007) identifies nearly one hundred real estate companies in the south of the state, of which about sixty subsidiaries are headquartered in the United States.

Lower and attractive real estate prices are driving US citizens to buy a second home in Los Cabos. So in the coming years it will become home of many US retirees. That is what the secretary of Tourism of Baja California Sur, Oscar Escobedo Carignan stated for the American newspaper La Opinion: "Until now the demographically dominant group consists of people with full mobility without special care, but soon we hope will become the destination of many pensioners, including those who need help in their daily lives" (Arenales 2008).

The most serious problem by the presence of so many foreigners in Los Cabos has to do with the occupation of the territory, including of course the beaches. Virtually, the entire peninsula is localted within the so-called forbidden zone established by Article 27 of the Constitution. The constitutional prohibition for foreigners, states that they can not own property within 50 kilometers from the coast and one hundred kilometers from the border, but this is practically ignored. There are two ways they can do it legally, from 1994 through the acquisition of a trust that no longer require any permission from Foreign Affairs, and now virtually renewable indefinitely (Bringas, 1989). The other way is to register a company in Mexico (Cabral, 2007).

The indefinite renewal of the trust is the most worrying aspect, this way, foreigners are allowed to acquire permanent rights of territory and further violate the constitutional ban. For Cabral (2006), this situation is particularly serious in the case of Baja California Sur, because its geographical position, its proximity to the United States and its isolation from the rest of the country, makes its sovereignty very vulnerable.

About this, Ignacio Ramirez (in Cabral, 2007) conducted a special report in which he shows that "Americans and Canadians speculators have grabbed the best beaches and grounds of national heritage. In Baja California Sur, a lot of beaches and coastlines are in hands of foreign businessmen, who have become exclusive places without access to Mexican citizens, there are fences, gates, barbed wire and chains to avoid accesses. There are other inaccessible places, hotels and settlements of foreigners who can be reached only by sea or by air. In addition, large real estate companies ignore the General Law of National Assets, so they exploit national heritage. Along the peninsula of Baja California Sur, many foreigners have illegally appropriated land, ranches and houses offered in Mexico, USA and Canada".

\subsubsection{Environmental effects: erosion and pollution}

\section{of beaches}

The real estate developments that respond to the demand for this segment of tourism are set in coastal areas of the region causing beach-sand erosion, by the carelessness of those who design the projects. There is little attention to integrating landscape and is common to see these large towers that break the harmony of the environment. In addition, the water discharged into the sea without being properly treated, creates problems of pollution and damaging the ecosystem of the inhabitants and the economy of some fishermen.

The federal government is allowing all building projects in the region, with little or poor verification before the constructions. A high percentage of development projects are initiated without the authorization of the Federal Attorney for Environmental Protection. It is taken by common agreement the decision these residential projects are priority to job creation.

The environmental sector has a weak presence in the three destinations analyzed in this paper; local governments have a policy of economic development, not considering compliance with environmental regulations. For Salazar (2009), the residential demanding needs in Los Cabos are very important; this poses a political problem because it affects the sovereignty over the ownership of national coasts and shorelines. Also creates an imaginary boundary that discriminates national tourists, local service providers, and indigenous populations.

Around the corridor of Los Cabos, it has become an excessive abuse of existing sand dunes, causing the destruction of these by the constant use of trailers, which is damaging the flora and the fauna of the 
region. For Salazar (2009), these desert areas of northwest Mexico are biodiversity reserves that are endangered by capitalist greed.

Since residential tourists demand amenity areas and panoramic views, in all the three cases, the buildings most demanded by them are located in dunes near the beach. Real estate developers for these constructions dig the mountains causing an obvious impact on the flora and fauna of the region.

In these territories there are nature reserves and marine areas protected where local people is prohibitied to fish. Many of them have been imprisoned actually (Heras, in Salazar, 2009), while the Federal Ministry of Agriculture and Fishing ignores large vessels exploding tons of marine resources for international markets (Caccavari, in Salazar, 2009).

Tourism and immigration brings urban settlements with high demand of water, and therefore, the little water in the desert has lowered and increased saltwater intrusion. Mangrove areas are razed to lift hotels and condominiums, golf courses replace the sand dunes, and motorized type entertainment ends with the desert flora (Enriquez, 2008).

The coastal tourist development facilitates the rapid deterioration of the natural environment; the desert landscape is replaced by scenarios breaking with the flora and fauna of the region. The architecture is an oasis of stereotypical representation of Mexico or the US-led consumption.

In Puerto Penasco what is significant is that the environment is used by the hotel and real estate business as mere rhetoric of sustainable projects, given the location of Puerto Penasco between two areas of ecological reserve (Biosphere of the High Gulf of California and Pinacate). The discourse of sustainable and environmental care is set as the background of public policy, but the negative effects on the environment are:

- Predation of desert landscape and the appearance of golf courses and hotels instead,

- The increase in per capita consumption of water, despite the progressive lowering of the few aquifers in areas with less percentage of annual rainfall in North America,

- High consumption of electrical energy in the maintenance of artificial environments in an area of the most extreme climate of North America (Enriquez, 2008).

Mexican tourism promotion in the international market transformed the region in northwest Mexico, by attracting large numbers of international visitors. The balance is a full scene of major structural, cultural and environmental conflicts (Salazar, 2009).

\section{CONCLUSIONS}

According to previous studies, as well as the observation during the field work of the author, the arrival of residential tourists to Mazatlán, Los Cabos and Puerto Peñasco has been a source of income and employment for local people by construction projects and daily consumption and services. But their arrival has had serious social and environmental impacts on host communities. In the three locations studied, inequality and social polarization is observed. The change in use of land and resources grabbing is alarming. Also real estate developments have caused beach erosion, and in the case of Puerto Penasco and Los Cabos, in the dunes. These developments have also led to increased pollution problems, damaging the ecosystem, and the economy of some fishermen.

The urbanism of residential tourism cities tend to be defensive, ie, physically have barriers that keep isolated to internal residents from local population. In the case of Puerto Penasco and Los Cabos there are a greater number of US citizens who inhabit these defensive urban complexes than in Mazatlan. This may change in Mazatlan by the recent construction of several condominium towers located near the sea. These residential complexes in the three destinations usually burst with the image and the harmony of the environment.

Culturally, residential tourism has impacted on religious and gastronomic traditions, adopting local residents practices brought by Americans in their cultural baggage. The cultural perception of mexicans towards residential tourists is so far positive and they live in relative harmony.

The biggest problem we see in this investigation is the occupation of the territory and social polarization in the three locations studied. By their economic power, residential tourists have access to the best residential areas near the beaches, even privatizing them. And in the case of Mazatlan, hogging the historic buildings. Moreover, there is a local 
population impoverished and often lacking basic resources such as water.

Comparatively, in Puerto Penasco and Los Cabos is more noticeable this economic and social duality than Mazatlan. In these two destinations, residential tourists have built invisible barriers, such as distrust, that somehow isolated them from the local population.

Just as Mario Gaviria (1974 and 1976) and Francisco Jurdao (1979) had already pointed out forty years ago in Spain, now in Mexico we are witnessing a neocolonialism of quality space. In which foreigners, mainly US citizens, because of the economic power they have, cause these social and environmental impacts that we point in this paper.

Our approach in this paper is critical, but we are not against the residential tourism, we believe it should be regulated and above all organized. Local governments of the three destinations can turn this mobility into an important lever for regional development. We refer not only to the economic benefit, but also to the human capital.

\section{BIBLIOGRAPHY}

Aledo, A., Mazon, T. (2004). "Impact of residencial tourism and the destination life cycle theory" in Pineda \& Brebbia (Eds.), Sustainable Tourism (pp.25-36). Southampton, Boston: Witpress.

Aledo, A. (2008). De la tierra al suelo: la transformación del paisaje y el nuevo turismo residencial. ARBOR Ciencia, Pensamiento y Cultura, núm. 729, enero-febrero, 99113.

Aledo, A., García, H. \& Ortiz, G. (2010). Análisis de mapas causales de impactos del turismo residencial. EMPIRIA. Revista de metodología de ciencias sociales, vol. 20, julio-diciembre, 61-86.

Aledo, A., Tristan, L., Ortiz, G. and García-Andreu, H. (2013). El turismo residencial internacional en el nordeste de Brasil: un análisis de partes interesadas. Revista Española de Investigaciones Sociológicas, 142, 3-24.

Arenales, Y. (April, 27, 2008). Jubilación en Baja. La Opinión, 4B. Balslev, H. (2008). Negotiating Membership in a Mexican Transnational Community. A study of north American Immigrants in a Mexican Border Town. Diálogos Latinoamericanos. Num 14, 1-18.

Barboza, E. (2016). Ciudades amuralladas del siglo xxi: producción del espacio y colonialidad en el turismo de playa intramuros en Guanacaste, Costa Rica. Revista latino americana de turismologia. Juiz de Fora v.2, n.1, 71-83.
Benson, M. and O'Reilly, K. (2009). Lifestyle Migration: Expectations, Aspirations and experiences. London: Ashgate.

Bielza de Ory, V. and Bohl, R. (2009). "El turismo residencial y su impacto en la estructura territorial de Lima Metropolitana" in Mazón, et al (Eds). Turismo, Urbanización y estilos de vida. Las nuevas formas de movilidad residencial. Icaria.

Bozic, S. (2006). The achievement and potencial of International Retirement Migration Resaearch: The need for disciplinary Exchange. Journal of ethnic and migration Studies, Vol. 32 No 8, 1415-1427.

Bringas, N. (1997). Las dos caras del turismo: Beneficios económicos contra costos socioculturales y ecológicos. El caso de México. Fementum, Miradas sobre América Látina, Año 7 num. 18. 89-116.

Cabral, M. (2006). Migración y Desarrollo, el contextonacional y estudios de caso en Los Cabos y La Paz Baja California Sur. (Coord). La Paz, BCS: Universidad Autónoma de Baja California Sur.

Carrasco, B. (2008). Urbanizaciones turísticas privadas a partir del imaginario social: desarrollo inmobiliario y cultura en Puerto Peñasco, México. Topofilia. Revista de Arquitectónica, Urbanismo y Ciencias Sociales. Hermosillo: Centro de Estudios de América del Norte, El Colegio de Sonora, September 1, vol. I, núm. 1. 25-38-

Cañada, E. (2007). Turismo y Desarrollo: Herramientas para una mirada crítica. Ed. Enlace. Managua.

Cañada, E. (Coord.) (2013). Turismo en Centroamérica: Un diagnóstico para el debate. Managua: Ed. Enlace.

Cañedo, S. (May 6, 2019). Vecinos de Fraccionamiento Gaviotas, en Mazatlán, protestan por departamentos en la zona. Noroeste, 3B.

Contreras, A. (July 20, 2009). Edificaciones prohibidas en el Centro Histórico. Noroeste, 2B.

Croucher, S. (2009). The other side of the fence. American migrants in Mexico. Austin: University of Texas Press.

Demajorovic, J; Aledo, A; Landi, B. \& Mantonavi, A. (2011). Complejos turísticos residenciales. Análisis del crecimiento del turismo residencial en el Mediterráneo español y en el Litoral Nordestino (Brasil) y su impacto socio-ambiental. Estudios y Perspectivas en Turismo, vol. 20, núm. 4, 772-796.

Enriquez, J. (2008). Segregación y fragmentación en las nuevas ciudades para el turismo. Caso Puerto Peñasco, Sonora en México. Topofilia. Revista de Arquitectónica, Urbanismo y Ciencias Sociales. Hermosillo: Centro de Estudios de América del Norte, El Colegio de Sonora, vol. I, núm. 1. 39-48.

Enriquez, J. (2009). Hacia un discurso hermenéutico dialéctico transformacional del urbanismo y el turismo en la dimensión de los mercados turísticos emisores. Caso China-México. Topofilia. Revista de Arquitectura, Urbanismo y Ciencias Sociales. Hermosillo: Centro de Estudios de América del Norte, El Colegio de Sonora, vol. I, núm. 3. 47-60. 
Enriquez, J. \& Cristina L. (2015). Impacto del turismo residencial en Bahía de Kino y San Carlos. Topofilia. Revista de Arquitectura, Urbanismo y Ciencias Sociales. Hermosillo: Centro de Estudios de América del Norte, El Colegio de Sonora, vol. V, núm. 1. 25-38.

Gascon, J. \& Cañada, E. (2016). Urbanizar el paisaje: turismo residencial, descampesinización, gentrificación rural. En Gascon, Jordi and Ernest Cañada (Coords). Una introducción Turismo Residencialy Gentrificación Rural. Tenerife, España, Colección Pasos.

Gaviria, M. et al. (1974). España A go go. Turismo chárter y neocolonialismo del espacio. Madrid: Ediciones Turner.

Gaviria, M. (1976). El Turismo de invierno yel asentamiento de extranjeros en la provincia de Alicante. Instituto de estudios alicantinos.

Gonzalez, G. (2012). Impacto sociopolítico y ambiental del proyecto turístico en el centro histórico de Zacatecas, México. Turydes, Revista de investigación en turismo y desarrollo local. Vol. 5 Num. 13. 38-50.

Gonzalez, L. \& Santana, J. (2009). Las inversiones inmobiliarias en destinos turísticos del litoral mexicano a debate. Topofilia. Revista de Arquitectura, Urbanismo y Ciencias Sociales. Hermosillo: Centro de Estudios de América del Norte, El Colegio de Sonora, vol. I, núm. 3. 12-25.

Guido, S. (2007). ¿Desarrollo turístico regional? Monitoreo de los desarrollos turísticos e inmobiliarios costeros del noroeste de México 2005-2006. ALCOSTA, Alianza para la sustentabilidad del Noroeste Costero, A.C.

Gustafson, P. (2008). Transnationalism in retirement migration: The case of north European retirees in Spain. Ethnic and Racial Studies, Vol. 31 No. 3. 451-475.

Hidalgo, R. \& Zunino, H. (2011). La urbanización de las áreas periféricas en Santiago y Valparaíso: el papel de las relaciones de poder en el dibujo de la geografía socioresidencial. Revista latinoamericana de estudios urbano regionales, (37), 111. 79-105.

Hiernaux, D. (2009). Los imaginarios del turismo residencial: experiencias mexicanas in Mazón, et al (Eds). Turismo, Urbanización y estilos de vida. Las nuevas formas de movilidad residencial. Icaria.

Hiernaux, D. (2005). La promoción inmobiliaria y el turismo residencial: el caso mexicano. Scripta Nova, vol. IX, núm. 194. 36-49.

Huber, A. (2005). Retirados suizos en la Costa Blanca. in Rodríguez Vicenteetal (Eds.). La migración de europeos retirados en España. Consejo Superior de Investigaciones Científicas. Madrid.

Huete, R. et, al (2008). ¿De qué hablamos cuando hablamos de turismo residencial?. Cuadernos de turismo, No 22; 101-121.

Huete, R. \& Mantecón, A. (2012). Introducción. Sobre la construcción social de los lugares. In Tomás Mazón, Raquel Huete y Alejandro Mantecón (eds.), Construir una nueva vida. Los espacios del turismo y la migración residencial. Santander.
Huete, R. Mantecón, A. \& Mazón, T. (2008). ¿De qué hablamos cuando hablamos de turismo residencial. Cuadernos de Turismo, núm. 22, julio-diciembre, 101121.

Instituto Nacional de Migración (INM) (2015). Población estadounidense en los estados de la República Mexicana. A través del Instituto Federal de Acceso a la Información Pública (IFAI) Folio No. 0411100057515.

Janoschka, M. (2008). Identity politics as an expression of European Citizenship practice: Participation of transnational migrants in local political conflicts. In Remus et al. The Making of world society. Rutger University and Transaction Publishers.

Jurdao, F. (1979). España en venta: Compra de suelos por extranjeros y colonización de campesinos en la Costa del Sol. Madrid: Editorial Ayuso.

Jurdao, F. \& Sánchez, M. (1990). España, Asilo de Europa. Barcelona: Planeta.

Lizarraga, O. (2012). La Transmigración Placentera. Movilidad de estadounidenses a México. México: IPN and UAS.

Lizarraga, O. (2014). Percepción cultural entre residentes extranjeros y habitantes locales en un destino turístico mexicano. El caso de estadounidenses en Mazatlán, Sinaloa. Investigaciones Turísticas, num. 7, 47-70.

Martinez, C. (2008). Turismo y planeación urbana en Puerto Peñasco. El caso de los asentamientos humanos del núcleo urbano original, 2000-2007. Topofilia. Revista de Arquitectónica, Urbanismo y Ciencias Sociales. Hermosillo: Centro de Estudios de América del Norte, El Colegio de Sonora, vol. I, núm. 1. 35-48.

Mazon, et al (Eds) (2009). Turismo, Urbanización y estilos de vida. Las nuevas formas de movilidad residencial. Icaria.

Mazón, T. and Aledo, A. (2005): El dilema del turismo residencial: ¿turismo o desarrollo inmobiliario. In Mazón, T. y Aledo, A. (Eds.) Turismo residencial y cambio social. Nuevas perspectivas teóricas y empíricas. Aguaclara. Alicante. 13-30.

Mendez, E. (2008). Imaginario del lugar. Topofilia. Revista de Arquitectónica, Urbanismo y Ciencias Sociales. Hermosillo: Centro de Estudios de América del Norte, El Colegio de Sonora, September 1, vol. I, núm. 12-29.

Muller, D. (2019). A research agenda for tourism geographies. Cheltenham: Edward Elgar Publishing,

Oehmichen, C. (2013). Una mirada antropológica al fenómeno del turismo. In Oehmichen, Cristina (Ed.) Enfoques antropológicos sobre el turismo contemporáneo. México D.F: Universidad Autónoma de México, Instituto de Investigaciones antropológicas.

Peraza, B. \& Santamaría, A. (2017). ¿ ¿Turistas o inmigrantes estadounidenses? Identidad y economías étnicas en mazatlán, sinaloa (méxico). Revista latino americana de turismologia. Juiz de Fora, v.3, n.2, 24-37.

Ramirez, J. (2006). El agua en Mazatlán: Una visión transdisciplinaria. México: Gobierno del Estado de Sinaloa y Universidad Autónoma de Sinaloa. 
Rodriguez, Vicenteet al Eds. (2005). Lamigración de europeos retirados en España. Madrid: Consejo Superior de Investigaciones Científicas.

Salazar, A. (2009). iLa gran barata!: el plan de SECTUR en las costas del Pacífico mexicano para la población baby boomer: consecuencias socioculturales y medioambientales. Topofilia. Revista de Arquitectura,
Urbanismo y Ciencias Sociales. Hermosillo: Centro de Estudios de América del Norte, El Colegio de Sonora, April 1, vol. I, núm. 3. 69-80.

Serrano, J. (2003). Las viviendas de segunda residencia en la sociedad del bienestar. El caso de un país turístico: España. Cuadernos de Turismo, núm. 12, 53-75.

Processo Editorial / Editorial Process

Editor Chefe/Editor-in-chief: PhD Thiago D. Pimentel (UFJF).

Recebido/ Received: March 25, 2019; Aceito/Accepted: November 27, 2019; Publicado/Published online: December 31, 2019. Artigo original / Original paper. Seção revisada às cegas por pares / Double blind review section. 